\title{
АБ'ЁМ І СКЛАД УНІВЕРСАЛЬНЫХ АДЗІНАК Ў ПАРЭМІЯЛАГІЧНЫМ ФОНДЗЕ БЕЛАРУСКАЙ МОВЫ
}

\author{
Юлія Петрушэўская
}

\author{
Магілёусскі дзяржаўны ўніверсітэт імя А. А. Куляшова \\ Mogilev State A. Kuleshov University \\ вул. Касманаўтаў, 1, Махілёў, 212022, Рэспубліка Беларусь \\ ivanov-msu@mail.ru
}

Петрушевська Ю. Обсяг і склад універсальних одиниць у паремійному фонді білоруської мови

У статті досліджено структурно-семантичні особливості паремій білоруської мови. Витлумачено поняття пареміологічної універсалії. До таких одиниць уналежнено прислів'я, що мають абсолютні відповідники в різних мовах. Пареміологічні універсалії спродуковані в різних мовах за одними й тими ж структурно-семантичними моделями, однак не детерміновані мовними контактами.

Акцентовано на особливостях і принципах фіксації досліджуваних універсальних одиниць. Окреслено функціонування понад 75 універсальних прислів 'їв у білоруській мові

Ключові слова: білоруська мова, лінгвістична універсалія, прислів'я, пареміологічна універсалія.

Петрушевская Ю. Объем и состав универсальных единиц в паремиологическом фонде белорусского языка

В статье исследуются структурно-семантические особенности паремиологических единиц белорусского языка. Определяется понятие паремиологической универсалии. К таким единицам относятся пословицы, имеющие точные соответствия в различных языках. Паремиологические универсалии образуются в разных языках по одной структурно-семантической модели, но не детерминированы языковыми контактами. Акцентируется внимание на особенностях и принципах фиксации исследуемых универсальных единиц. Установливается функционирование более 75 универсальных пословиц в белорусском языке.

Ключевые слова: белорусский язык, лингвистическая универсалия, пословица, пословичная универсалия

() Ю. Петрушэўская, 2018. 
Petrushevskaya Yu. The Volume and Composition of Universal Units in the Belarusian Proverbial Fund

The research material is represented by proverbs that are the part of the Belarusian paremiological minimum, the Belarusian basic paremiological stock, units of the modern Belarusian literary language. The subject of the study are universal proverbs.

The purpose of research is to refine the concept universals in the paremiological fund, and that is the basis for defining the proverbs-universals in the Belarusian language. The methodological basis of the study is (1) the comparative method taking the Belarusian language as the basis, (2) the linguistic methods of structural and semantic modeling of proverbs.

The article defined the concept of proverbial universals. These are proverbs that have exact correspondences in different languages, but are not determined by the language contacts. Such proverbs are formed in different languages according to one structural-semantic model, but are not determined by the language contacts. The principles of fixing universal proverbs were defined. The universal proverbs were installed in the Belarusian language.

The study found that at least 75 proverbs-universals are actively used in Belarusian. Such proverbs-universals must be described systematically, comprehensively and separately in a special linguistic dictionary.

Key words: Belarusian, linguistic universal, proverb, proverbial universal

\section{Пастаноўка праблемы i яе сувязь 3 важнымі} навуковымі задачамі. Прыказкі ў розных мовах свету бываюць вельмі падобныя адна на адну па зместу, лагічнай пабудове, структурных мадэлях, лексічнаму складу, сінтаксічнай арганізацы, выкарыстаных вобразах, сродках выразнасці, спосабах ужывання і інш. Такое падабенства выклікала пошукі агульных (універсальных) уласцівасцей прыказак як фразавых тэкстаў і як устойлівых адзінак мовы. Агульныя (універсальныя) уласцівасці прыказак вывучаюцца па-за тыпалогіяй моў і лінгвістычнай універсалогіяй, паколькі месца і статус прыказак у моўнай сістэме, заканамернасці іх мадэлявання як уласна моўных утварэнняў застаюцца недакладна вызначанымі. Аднак гэта не перашкаджае выяўляць і дыферэнцыяваць у розных мовах агульныя 3 іншымі мовамі прыказкавыя адзінкі і элементы формы і зместу прыказак.

Дакладнае размежаванне спецыфічнага (нацыянальнага) і агульнага (універсальнага ці інтэрнацыянальнага) у беларускай парэміялогіi, як падкрэсліў Я. Іваноў у сваім дакладзе на XV Міжнародным з'ездзе славістаў, з'яўляецца адной 
3 актуальных праблем вывучэння прыказак беларускай мовы [Ivanov / Иванов 2013]. Вырашэнне гэтай праблемы мае тэарэтычную значнасць як у галіне тыпалогіi моў і лінгвістычнай ўніверсалогіі (пры вывучэнні парэміялагічных адзінак беларускай мовы на фоне іншых моў свету), так і ў лінгвакультуралагічным плане пры выяўленні нацыянальнакультурнай адметнасці парэміялагічных адзінак беларускай мовы [Ivanou / Іваноў 2009а; Ivanou / Іваноў 2016].

Аналіз апошніх даследаванняў і публікацый. Самай маштабнай па аб’ёме, разнастайнасці фактычнага матэрыялу і атрыманых выніках з'яўляецца класіфікацыя прыказак розных моў свету па лагічна-семіятычных тыпах і лагічна-тэматычных групах Р. Пермякова [Permyakov / Пермяков 1988a; Permyakov / Пермяков 1988б]. Паколькі мяркуецца, што вызначаныя тыпы i групы прыказак павінны сустракацца ва ўсіх мовах свету, то такія тыпы i групы мэтазгодна кваліфікаваць як спісы парэміялагічных універсалій. Не менш значнай, хоць і не такой маштабнай, як класіфікацыі Р. Пермякова, з'яўляецца спроба Дж. Пацалаі ўстанавіць прыказкавыя адзінкі, якія супадаюць ці вельмі блізкія паводле лексічнага складу і граматычнай арганізацыі ў еўрапейскіх мовах розных сямей і груп, а таксама ў арабскай, персідскай, кітайскай, японскай мовах, у санскрыце i іншых мовах свету [Paczolay 1997]. Прыказкі, якія вызначыў Дж. Пацалаі, мэтазгодна разглядаць як спіс парэміялагічных фрэквенталій (адзінак, што ўласцівы не ўсім мовам свету, а толькі пэўнай, дастаткова вялікай колькасці моў).

Універсальныя адзінкі прыказкавага фонду беларускай мовы ніколі спецыяльна не даследаваліся, хоць паходжанне і ужжыванне ў іншых мовах тых прыказак, што функцыянуюць у сучаснай беларускай літаратурнай мове, разглядаюцца ў кнізе I. Лепешава "Парэміялогія як асобны раздел мовазнаўства" [Lepeshau / Лепешаў 2006] і апісваюцца ў яго ж даведніку “Этымалагічны слоўнік прыказак” [Lepeshau / Лепешаў 2014]. Метадалогія міжмоўнага супастаўлення парэміялагічных адзінак распрацавана Я. Івановым на матэрыяле прыказак беларускай мовы і рускай, англійскай, нямецкай, польскай моў [Ivanov 2007; Ivanou / Іваноў 2011; Ivanou / Іваноў 2006б; Ivanov / Иванов 
2007; Ivanou / Іваноў 2007; Ivanou / Іваноў 2009б]. Агульнасць шэрагу прыказкавых адзінак беларускай мовы 3 іншымі мовамі свету была ўстаноўлена ў нашых папярэдніх даследаваннях [Petrusheuskaya / Петрушэўская 2015a; Petrusheuskaya / Петрушэўская 2015б; Petrusheuskaya / Петрушэўская 2015в; Petrusheuskaya / Петрушэўская 2016a; Petrusheuskaya / Петрушэўская 2016б; Petrusheuskaya / Петрушэўская 2017в].

Мэта даследавання - удакладніць паняцце ўніверсаліі ў дачыненні да парэміялагічнага фонду мовы і на гэтай падставе вызначыць аб'ём і састаў універсальных прыказкавых адзінак у беларускай мове.

Метадалагічная аснова даследавання складаецца (1) з супастаўляльнага метаду ў кірунку ад беларускай мовы да іншых моў, (2) лінгвістычнага метаду структурна-семантычнага мадэлявання прыказак. Фактычны матэрыял даследавання прыказкі, якія ўваходзяць у парэміялагічны склад сучаснай беларускай літаратурнай мовы [Lepeshau / Лепешаў 2011], у парэміялагічны мінімум беларускай мовы [Kotova / Котова 2000; Ivanou / Іваноў 2004; Ivanov 2008; Ivanou / Іваноў 2017: 99_ 106] і ў яе асноўны парэміялагічны фонд [Ivanou / Іваноў 2004; Ivanou / Іваноў 2006a; Ivanou / Іваноў 2017: 85-99], і якія маюць свае дакладныя адпаведнікі ў іншых еўрапейскіх і нееўрапейскіх мовах, паводле дадзеных фундаментальных полілінгвальных парэміяграфічных крыніц [Strauss 1994; Paczolay 1997; Proverbia et dicta 2008; Mudrost' slova / Мудрость слова 2015].

Выклад асноўнага матэрыялу даследавання. Паняцце ўніверсаліі ў дачыненні да прыказак не мае агульнапрынятага вызначэння i ўжываецца адносна рэдка. Так, Р. Пермякоў кваліфікуе як “ўніверсальны” толькі распрацаваны ў выключна прыкладных мэтах “тэматычны паказальнік”, прызначаны для размяшчэння прыказак у парэміялагічных зборніках [Permyakov / Пермяков 1988в]. Разам 3 тым многія парэміёлагі шырока карыстаюцца тэрмінам “агульны” (common), які ужжываюць у дачыненні як да ўласна ўніверсальных прыказак, так і да тых прыказкавых адзінак, якія распаўсюджаны ў многіх мовах свету. У такіх выпадках паняцце "агульнае" не дыферэнцыруецца на “ўніверсальнае” і “інтэрнацыянальнае”, з прычыны чаго ўзнікае 
метамоўная і метадалагічная блытаніна ў кваліфікацыі прыказак як “агульных", як “універсальных" і як “інтэрнацыянальных". У гэтай сувязі ў парэміялогіі патрабуецца ўдакладненне аб'ёму паняцця “ўніверсальнае" ў адносінах, найперш, да паняцця “інтэрнацыяльнае”.

На наш погляд, да ўніверсальных прыказак адносяцца адзінкі, якія, па-першае, маюць у іншых мовах аналагі, не абумоўленыя моўным раством ці моўнымі кантактамі, а падругое, пабудаваны па структурна-семантычных прыказкавых мадэлях, што рэалізуюцца ў іншых мовах і не абумоўлены ні моўным раством, ні моўнымі кантактамі. Універсальныя прыказкі могуць адрозніваюцца паводле лексічнаму складу і граматычнай арганізацы ў розных мовах за выключэннем апорных (ключавых) слоў і лагічна-сінтаксічнай структуры, што адлюстроўваюць універсальныя рэаліі і вобразы ў межах універсальнай прыказкавай структурна-семантычнай мадэлі (ці яе пэўных варыянтаў) [Petrusheuskaya / Петрушэўская 2017a; Petrusheuskaya / Петрушэўская 2017б].

Агульныя з многімі мовамі адзінкі ў прыказкавым фондзе беларускай мовы акрэслены ў этымалагічным слоўніку прыказак I. Лепешава [Lepeshau / Лепешаў 2014], дзе кваліфікуюцца як тыя, што “ўжываюцца (як калька / паўкалька) у розных мовах свету” (30 адзінак), “(як калька) у многіх мовах свету” (10 адзінак), “у розных мовах свету” (4 адзінкі), “у многіх мовах свету” (2 адзінкі), “шырокаўжывальная ў розных мовах свету” (1 адзінка), “бытуе ў скалькаваным выглядзе ў розных мовах свету” (1 адзінка). Усяго да такіх адзінак аднесена 47 прыказак, што складае каля $12 \%$ ад агульнай колькасці іх у даведніку. На жаль, у этымалагічным слоўніку I. Лепешава за вельмі рэдкім выключэннем не падаюцца іншамоўныя аналагі беларускіх прыказак “у многіх мовах свету”, а таксама не адзначаюцца парэміяграфічныя крыніцы, на падставе якіх вызначаецца агульнасць тых ці іншых прыказак “для розных моў свету”. Мяркуючы па слоўнікавых дэфініцыях I. Лепешава, такія прыказкавыя адзінкі адрозніваюцца ад тых, што ўжываюцца толькі ў пэўных мовах (паводле геаграфічнага або генетычнага крытэрыяў) - “(як калька) у многіх еўрапейскіх мовах" 
(17 адзінак), “(як калька / паўкалька) у розных еўрапейскіх мовах" (14 адзінак), “у розных еўрапейскіх мовах” (3 адзінкі), “(як калька) амаль ва ўсіх еўрапейскіх мовах" (1 адзінка), “агульная (як калька) для многіх еўрапейскіх моў” (1 адзінка), "ва ўсходнеславянскіх, польскай і іншых еўрапейскіх мовах" (1 адзінка), "ва ўсходнеславянскіх, польскай і іншых мовах" (1 адзінка) i г.д., што аднак таксама не пацвярджаецца спасылкамі на парэміяграфічныя крыніцы. Усяго да такіх адзінак аднесена 38 прыказак, што складае каля 9\% ад агульнай колькасці прыказкавых адзінак у этымалагічным даведніку I. Лепешава. Такім чынам, больш за 1/5 усіх прыказак, паходжанне якіх апісваецца ў слоўніку, ужываецца акрамя беларускай мовы як у “многіх еўрапейскіх мовах", так і ў “розных мовах свету”.

Калі ж звярнуцца да кожнай 3 адзначаных прыказак паасобку, то застаецца незразумелым, чаму сфера ужжывання той ці іншай адзінкі акрэсліваецца то межамі еўрапейскімі, то межамі ўсяго свету, то ўвогуле ніяк не вызначаецца. Так, шмат выслоўяў аднолькавага (звычайна літаратурнага) паходжання ў этымалагічным слоўніку І. Лепешава кваліфікуюцца чамусьці па-рознаму. Так, Адзін за ўсіx, а ўсе за аднаго “ужжываецца (як калька) у розных мовах свету" [Lepeshau / Лепешаў 2014: 16], Кожны салдат носіиь у ранцы маршальскі жэзл “ужываецца (як паўкалька) у розных еўрапейскіх мовах" [Lepeshau / Лепешаў 2014: 66], а вось Aneтыт прыходзіиь у часе яды вызначаецца толькі як “паўкалька з французскай мовы” [Lepeshau / Лепешаў 2014: 20], хоць у даведніку Дж. Пацалаі гэтае выслоўе мае аналагі ў многіх еўрапейскіх мовах [Рaczolay 1997: 447-448]. Шмат якія адзінкі, што “ўжываюцца ў розных / многіх мовах свету” (паводле этымалагічнага слоўніка І.Я. Лепешава), нельга кваліфікаваць як універсальныя $з$ прычыны наяўнасці ў іх адной, агульнай для ўсіх моў тэкставай крыніцы (як правіла, сусветна вядомай) або мовы-донара (звычайна міжнароднай). Так, не могуць быць універсальнымі выслоўі, якія паходзяць 3 Бібліі, класічных філасофскіх ці літаратурных твораў, пашырыліся 3 вуснаў знакамітых асоб, з лацінскай ці з грэчаскай мовы часоў антычнасці, з сярэднявечнай латыні, з сучаснай англійскай мовы 
(Быциё вызначае свядомасиь; Грошы не пахнуцьь; Каментарыі лішнія; Лепш даваць, чылм прымаџь; Маўчанне - знак згоды; Многа шуму з нічога; Мой дом - мая крэпасиь; Мэта апраўдвае сродкі; На вайне як на вайне; Час - гэта грошы і да т. п.). Функцыянаванне такога кшталту выслоўяў у розных мовах свету 3'яўляецца вынікам моўных і культурных кантактаў (або паралельных, або паслядоўных), таму такія прыказкі мэтазгодна кваліфікаваць як інтэрнацыянальныя.

3 другога боку, многія прыказкі, сфера уужывання якіх зусім не абмяжоўваецца толькі беларускай мовай, беспадстаўна вызначаюцца як “уласна беларускія”. Паказальным у гэтай сувязі можна лічыць вызначэнне “беларускага" паходжання прыказкі Адна галава добра, а дзве <яшчэ> лепи (лепей) у этымалагічным слоўніку I. Лепешава [Lepeshau / Лепешаў 2014 : 18]. На самой справе гэта прыказкавая адзінка мае аналагі ў пяцідзесяці сямі мовах свету, што належаць да розных моўных сямей, i 3'яўляецца адным 3 двух варыянтаў універсальнай прыказкі Two / four / more eyes see more / better / farther than one / two V1 - Two heads / brains are better then one V2 [Paczolay 1997: 72-76]. Гэта ж датычыцца і прыказкі Ціхая вада грэблю рве [Lepeshau / Лепешаў 2014: 128], якая мае аналагі ў сарака шасці мовах свету розных моўных сямей і з'яўляецца адным 3 трох варыянтаў універсальнай прыказкі Still waters are / run deep / deepest (or have a deep bottom) V1 - Still waters wash away the bank V2 Keep away from still water or Still water is dangerous V3 [Paczolay 1997: 373-376]. Тое самае можна казаць і пра згаданую вышэй прыказку 3 вялікага грому <часамі, заусёды> маль дождж $<$ бывае > [Petrusheuskaya / Петрушэўская 2016а] і інш. У гэтай сувязі адной 3 прыкладных мэт вырашэння праблемы размежавання нацыянальнага і інтэрнацыянальнага ў беларускай парэміялогіі з'яўляецца стварэнне полілінгвальнага беларускаіншамоўнага парэміялагічнага слоўніка, дзе былі б апісаны прыказкавыя аналагі, паралелі i эквіваленты розных моў (на аснове структурна-семантычнага мадэлявання ў адносінах да беларускай мовы) [Petrusheuskaya / Петрушэўская 2015в].

Супастаўленне прыказак, што складаюць парэміялагічны фонд сучаснай беларускай літаратурнай мовы, парэміялагічны

( Ю. Петрушэўская, 2018. 
мінімум беларускай мовы і яе асноўны парэміялагічны фонд, 3 прыказкавымі адзінкамі іншых моў паводле полілінгвальных парэміяграфічных крыніц (у кірунку ад беларускай да іншых моў) дазваляе сцвярджаць, што ў беларускай мове ўжываецца каля 100 ўніверсальных прыказак. Напрыклад, да ўніверсальных адзінак, што ўжываюцца ў сучаснай беларускай літаратурнай мове [Lepeshau / Лепешаў 2011], можна аднесці на падставе фундаментальнага полілінгвальнага парэміялагічнага даведніка Дж. Пацалаі [Paczolay 1997] наступныя прыказкі: Адна бяда не ходзіиь <другую за сабою водзічь > (р. 59-64); Адна галава добра, а дзве <ямчэ> лепш (лепей) (р. 72-76); Адна ластаўка вясны не робіць (р. 49-53); Век жыві - век вучыся (р. 182-185); Воран ворану вачэй не выклюе (р. 96-99); Воўк ліняе, ды нораву не мяняе (р. 186-190); Высока лятаеш, але нізка сядзеш (р. 236-240); Выцягвай ножкі паводле адзёжкі (р. 267-271); Гара з гарою не сходзічиа, а чалавек з чалавекам заўсёды (р. 213-216); Да пары збан (жбан) ваду носіиь <ручка (вушка) адарвещца - збан паб'ециа> (р. 287-291); Дараванаму каню у зубь не глядзяць (р. 54-58); Добры пачатак - палавіна справы (р. 228-232); Дружба (прыящель) пазнаещчи ў няшчасиі (р. 159-164); Дьму без агню не бывае (р. 33-37); За дурной галавой нагам неспакой (небалазе) (р. 280-282); 3 вачэй (з воч) далоў $i$ з сэрияа вон (p. 165-169); 3 пустой бочкі многа шуму (р. 146-149); I сцень маюиь вушы (р. 142-145); Канец - дзелу вянеи (р. 277-279); Конь на чатырох нагах <i то> спатыкаещца (р. 155-158); Кроў людская не вадзіиа (р. 233-235); Куй жалеза, пакуль гарачае (р. 109-113); Лепш позна, чьми ніколі (р. 191-193); Лепш сініца у руиэ (у жмені), чьм журавель (жораў) у небе (р. 194-202); Лес усё чуе, а поле усё бачыць (р. 120-124); Меней гавары, болей пачуеш (р. 245-248); На адным месиь $i$ камень <мохам> абрастае (р. 100-103); На бога спадзявайся, а (ды) сам не давайся (р. 150-154); Не бойся таго сабакі, што брэша, а бойся таго, што лашчыщца (р. 44-48); Не усё тое золата, што блішчьщь (р. 125-130); Ніколі не адкладвай на заўтра, што можна зрабіць сёння (р. 87-91); Новая мятла па-новаму мяце (р. 92-95); У чужым воку саломку (саломінку) бачылм, а у сваім $<i>$ бервяна не заўважаем (р.131-136); Няпрошань 
(незапрошаны, нязваны) госиь горш за татарына (р. 224-227); Рука руку мые (р. 174-178); Свая кашуля (сарочка, рубашка) бліжэй да цела (р. 249-251); Сляпь сляпому не павадыр (р. 203-207); Хто пад кім яму капае, часта сам у яе ўпадае (p. 77-82); Хто не працуе (не робіць), той не есць (р. 256-258); Ціхая вада грэблю рве (р. 373-376); Цішэй едзеш - далей будзеш (p. 241-244); Шавеи заусёды <ходзіиь > без ботаў (p. 65-71); Што <ні> галава, то <i> розум (р. 83-88); Што пасееш, тое $i$ пажнеш (р. 38-39); Яблькк ад ябльні недалёка падае (коціџча) (p. 259-262); Якая клёпка, такая бочка, якая мачі, такая дочка (p. 137-141); Якое дрэва, такі <i> клін, які баџька, такі $<i>c b l н$ (p. 170-173) і г. д.

Усяго ў парэміялагічным фондзе сучаснай беларускай літаратурнай мовы (які складаецца з больш за 1500 адзінак) намі зафіксавана функцыянаванне больш за 75 (5\%) універсальных прыказак. Адносна невялікі аб'ём універсальных прыказкавых адзінак у складзе парэміялагічнага фонду сучаснай літаратурнай мовы не з'яўляецца паказчыкам іх удзельнай вагі ў парэміконе беларускай мовы, паколькі ўніверсальныя прыказкі складаюць заўважную частку ў асноўным парэміялагічным фондзе (8\%) беларускай мовы і яе парэміялагічным мінімуме (16\%).

Такая колькасць універсальных адзінак не з'яўляецца ні малой, ні вялікай. Сапраўдны аб’ём універсальных прыказак не можа быць вызначана ў мове абсалютна дакладна, паколькі залежыць ад эмпірычных дадзеных, абмежаваных, 3 аднаго боку, існуючымі полілінгвальнымі крыніцамі, а з другога боку, наяўнасцю фіксацый парэміялагічнага матэрыялу розных моў свету, яго паўнатой і даступнасцю даследчыку.

Разам 3 тым пры параўнанні удзельнай вагі ўніверсальных прыказкавых адзінак у складзе асноўнага парэміялагічнага фонду і парэміялагічнага мінімуму можна заўважыць тэндэнцыі дынамікі ўніверсальнага кампанента прыказкавай падсістэмы мовы. Так, больш вялікая колькасць універсальных прыказак у складзе парэміялагічнага мінімуму, чым ў складзе асноўнага парэміялагічнага фонду сведчыць пра тэндэнцыю прыказкавага складу беларускай мовы да павелічэння ролі ўніверсальнага кампанента (выбару носьбітамі мовы ва ўжыванне агульных 3

๑ Ю. Петрушэўская, 2018. 
іншымі мовамі адзінак за кошт знікнення моўных і культурных межаў у камунікацыі) і страты ролі нацыянальнага кампанента (адмова носьбітамі мовы ад ужывання спецыфічных адзінак, якія патрабуюць звароту на нацыянальнай культуры ў процівагу інтэрнацыянальным і глабалізацыйным працэсам сучаснасці).

\section{Высновы i перспектывы далейшых навуковых} даследаванняў. Далёка не ўсе прыказкі, якія функцыянуюць у сучаснай беларускай мове і ўспрымаюцца яе носьбітамі (у тым ліку і даследчыкамі) як уласна беларускія і на гэтай падставе інтэрпрэтуюцца як яе яскрава нацыянальны кампанент, на самой справе ўжываюцца толькі ў беларускай мове і маюць уласна беларускае паходжанне. Многія 3 такіх прыказак з'яўляюцца ўніверсальнымі, паколькі сустракаюцца ў аднолькавай ці вельмі блізкай лексічна-граматычнай форме ў іншых мовах свету, якія ніколі не мелі з беларускай мовай ні прамых, ні апасродкаваных моўных кантактаў. Універсальныя прыказкі ўзнікаюць у розных мовах і культурах незалежна, дзякуючы агульнасці чалавечага мыслення і аднолькаваму ці падобнаму ў жыцці розных народаў эмпірычнаму вопыту.

Аб'ём універсальных прыказкавых адзінак у беларускай мове адносна невялікі, не перавышае 5\% у парэміялагічным складзе літаратурнай мовы, аднак складае заўважную частку ў асноўным парэміялагічным фондзе і парэміялагічным мінімуме беларускай мовы (адпаведна 8\% і 16\%). Вызначэнне прыказак універсальнага характару дазволіла ўдакладніць аб'ём i склад нацыянальнага кампанента парэміялагічнага фонду беларускай мовы, унікнуць памылак у вызначэнні паходжання некаторых прыказкавых адзінак.

Перспектывай далейшага вывучэння прыказкавых адзінак універсальнага характару з'яўляецца сістэматызацыя і апісанне ix у межах спецыяльнага полілінгвальнага даведніка, дзе будуць адлюстраваны іншамоўныя адпаведнікі ўніверсальных прыказак беларускай мовы.

\section{Літаратура}

1. Англа-беларускі парэміялагічны слоўнік = English-Belarusian Paremiological Dictionary/ пад рэд. Я. Я. Іванова. Магілёў: МДУ імя А. А. Куляшова, 2009б. 240 с. 
2. Иванов Е. Е. Белорусская паремиология и афористика в общеевропейском контексте (актуальные проблемы изучения). Nationales und Internationales in der slawischen Praseologie $=$ Национальное $u$ интернациональное в славянской фразеологии / Hrsg. H. Walter, V. M. Mokienko. Greifswald : E.M.A.-Universität, 2013. S. 111-116.

3. Иванов Е. Е., Мокиенко В. М. Русско-белорусский паремиологический словарь. Могилев : МГУ имени А. А. Кулешова, 2007. 242 с.

4. Іваноў Я. Я. Афарыстычныя адзінкі ў беларускай мове : манаграфія. Магілёў : МДУ імя А. А. Куляшова, 2017. 208 с.

5. Іваноў Я. Я. Да праблемы вызначэння асноўнага парэміялагічнага фонду беларускай мовы. Веснік Беларускага дзяржаўнага ўніверсітэта. Серыя 4, Філалогія. Журналістыка. Педагогіка. 2006а. № 3. С. 103-109.

6. Іваноў Я. Я. Раманава Н. К. Беларуска-нямецкі парэміялагічны слоўнік = Belarussisches-Deutsch paremiologisches Wörterbuch. Магілёў: МДУ імя А. А. Куляшова, 2006б. 108 с.

7. Іваноў Я. Я. Параўнальнае мовазнаўства і нацыянальна-культурная семантыка мовы (на матэрыяле парэміялагічных адзінак). Наџыянальная мова $i$ нацьыянальная культура: аспекты уззаемадзеяння : зб. навук. арт./ рэд. Д. В. Дзятко. Мінск : БДПУ імя М. Танка, 2009а. С. 54-57.

8. Іваноў Я. Я. Парэміялагічныя сістэмы беларускай i рускай моў: падабенствы i разыходжанні. Філологічні студії : Науковий вісник Криворізького державного педагогічного університету. Кривий Ріг : “Видавничий дім”, 2011. Вип. 6. Ч. 2. С. 53-63.

9. Іваноў Я. Я., Іванова С. Ф. Польска-беларускі парэміялагічны слоўнік = Polsko-białoruski słownik paremiołogiczny. Магілёў : МДУ імя А. А. Куляшова, 2007. 192 c.

10. Іваноў Я. Я. Сацыялінгвістычныя параметры беларускіх прыказак (да праблемы вызначэння парэміялагічнага мінімуму і асноўнага парэміялагічнага фонду сучаснай беларускай літаратурнай мовы). Мова $і$ соиыбўм : зб. навук. прац / пад рэд. Я. Я. Іванова. Магілёў : Брама, 2004. С. 201-224.

11. Іваноў Я.Я. Універсальнае i нацыянальнае ў фразеалагічнай i парэміялагічнай падсістэмах беларускай мовы ў еўрапейскім моўным кантэксце (актуальнасць, метадалогія, перспектывы даследавання). Славянская фразеология в синхронии и диахронии: сб. науч. ст. / ред. В. И. Коваль. Гомель : ГГУ им. Ф. Скорины, 2016. Вып. 3. С. 46-49.

12. Котова М. Ю. Русско-славянский словарь пословиц с английскими соответствиями. Санкт-Петербург : Изд-во СПбГУ, 2000. 360 с.

13. Лепешаў I. Я., Якалцэвіч М. А. Тлумачальны слоўнік прыказак. Гродна : ГрДУ, 2011. 695 с.

14. Лепешаў І. Я. Парэміялогія як асобны раздзел мовазнаўства. Гродна : ГрдУ імя Янкі Купалы, 2006. 279 с.

15. Лепешаў І. Я. Этымалагічны слоўнік прыказак. Мінск: Вышэйшая школа, 2014. $141 \mathrm{c}$.

16. Мудрость слова сквозь века и народы: десятиязычный словарь фразеологических эквивалентов: около 700 латинских пословиц, поговорок, изречений / под ред. Н. А. Гончаровой. Минск : Беларуская навука, 2015. 479 с.

( Ю. Петрушэўская, 2018. 
17. Пермяков Г. Л. Классификация пословичных изречений. Система логической трансформации пословиц. Основы структурной паремиологии. Москва : Наука, 1988а. С. 11-33.

18. Пермяков Г.Л. О смысловой структуре и соответствующей классификации пословичных изречений. Основы структурной паремиологии. Москва : Наука, 1988б. С. 107-134.

19. Пермяков Г. Л. Универсальный тематический указатель. Ochoвbl структурной паремиологии. Москва : Наука, 1988в. С. 170-181.

20. Петрушэўская Ю. А. Да праблемы размежавання ўніверсальнага i інтернацыянальнага ў парэміялагічным фондзе мовы. Универсальное $u$ национальное в языковой картине мира : материалы II Междунар. науч. конф., 14-15 октября 2016 г. / ред. Н. В. Фурашова. Минск, 2017а. С. 193-196.

21. Петрушэўская Ю. А. Да праблемы размежавання ўніверсальных i інтэрнацыянальных адзінак у парэміялагічным фондзе беларускай мовы. Итоги научных исследований ученых МГУ имени А. А. Кулешова 2016 г.: материалы конференции, 25 января 1 февраля 2017 г. / под ред. Е. К. Сычовой. Могилев, 2017б. С. 113-115.

22. Петрушэўская Ю. А. Паходжанне і тэкставыя крыніцы некаторых універсальных прыказак у сучаснай беларускай мове. Текст. Язык. Человек: сб. науч. трудов : в 2 ч. / ред. С. Б. Кураш. Мозырь : МГПУ имени И. П. Шамякина, 2015а. Ч. 2. С. 120-122.

23. Петрушэўская Ю. А. Пра сферу ўжывання і паходжанне прыказкі $A \partial н а$ галава добра, а дзве лепи. Вестник Минского гос. лингв. ун-та. Серия 1, Филология. 2015б. № 5 (78). С. 84-96.

24. Петрушэўская Ю. А. Пра сферу ўжывання і паходжанне прыказкі 3 вялікага грому малы дождж. Роднае слова. 2016а. № 1. С. 44-47.

25. Петрушэўская Ю. А. Пра сферу ўжывання і паходжанне прыказкі Хто мажа, той $і$ едзе. Вестник Полоикого гос. ун-та. Серия А, Гуманитар. науки. 2016б. № 2. С. 138-144.

26. Петрушэўская Ю. А. Універсальны, інтэрнацыянальны і нацыянальны кампаненты парэміялагічнага фонду сучаснай беларускай літаратурнай мовы (на матэрыяле публіцыстычных тэкстаў). Філологічні студії : Науковий вісник Криворізького державного педагогічного університету. Кривий Ріг : ФОП Маринченко С. В., 2017. Вип. 16. С. 195-201.

27. Петрушэўская Ю. А. Універсальныя прыказкі ў беларускай мове (лексікаграфічны аспект). Усходнеславянскія мовы у сучаснай лексікаграфіi : зб. навук. арт. / навук. рэд. Д. В. Дзятко. Мінск : БДПУ імя М. Танка, 2015в. C. 84-87.

28. Ivanov E. "Paremiological Minimum" of the Belarusian Language. Даследаванні па германскай і славянскай філалогіi = Acta Germano-Slavica : зб. навук. арт. / пад рэд. Я. Я. Іванова. Магілёў : МДУ імя А. А. Куляшова, 2008. Вып. 3. С. 283-302.

29. Ivanov E., Feldman V. Principles of the Contrastive Description of Aphoristic Paremiology (in Belarussian and Russian Languages). Даследаванні па германскай і славянскай філалогіi = Acta Germano-Slavica : зб. навук. арт. / пад рэд. Я. Я. Іванова. Магілёў : МДУ імя А. А. Куляшова, 2007. Вып. 1. С. 85-97. 
30. Paczolay G. European Proverbs in 55 Languages, with Equivalents in Arabic, Persian, Sanskrit, Chinese, and Japanese. Veszprém (Hungary) : Veszprémi Nyomda, 1997. 528 p.

31. Proverbia et dicta: шестиязычный словарь пословиц, поговорок и крылатых слов / под ред. Н. А. Гончаровой. 2-е изд. Минск : Конкурс, 2008. $352 \mathrm{c}$.

32. Strauss E. Dictionary of European proverbs : 3 vols. London \& New York : Routledge, 1994. Vol. 1. XIII, 625 p. ; Vol 2. V, 627-1232 p. ; Vol. 3. V, 789 p.

\section{References}

1. Angla-belaruski parehmiyalagichny slounik $=$ English-Belarusian Paremiological Dictionary / pad red. Ya. Ya. Ivanova. Magilyou : MDU imya A. A. Kulyashova, 2009b. $240 \mathrm{~s}$.

2. Ivanov E. E. Belorusskaya paremiologiya i aforistika v obshcheevropejskom kontekste (aktual'nye problemy izucheniya). Nationales und Internationales in der slawischen Praseologie $=$ Nacional'noe $i$ internacional'noe $v$ slavyanskoj frazeologii / Hrsg. H. Walter, V. M. Mokienko. Greifswald : E.M.A.-Universität, 2013. S. 111-116.

3. Ivanov E. E., Mokienko V. M. Russko-belorusskij paremiologicheskij slovar'. Mogilev : MGU imeni A. A. Kuleshova, 2007. 242 s.

4. Ivanou Ya. Ya. Afarystychnyya adzinki u belaruskaj move : managrafiya. Magilyou : MDU imya A. A. Kulyashova, 2017. 208 s.

5. Ivanou Ya. Ya. Da prablemy vyznachehnnya asnounaga paremiyalagichnaga fondu belaruskaj movy. Vesnik Belaruskaga dzyarzhaunaga universiteta. Seryya 4, Filalogiya. Zhurnalistyka. Pedagogika 2006a. № 3. S. 103-109.

6. Ivanou Ya. Ya. Ramanava N. K. Belaruska-nyamecki paremiyalagichny slounik $=$ Belarussisches-Deutsch paremiologisches Wörterbuch. Magilyou : MDU imya A. A. Kulyashova, 2006b. 108 s.

7. Ivanou Ya. Ya. Paraunal'nae movaznaustva i nacyyanal'na-kul'turnaya semantyka movy (na matehryyale paremiyalagichnyh adzinak). Nacyyanal'naya mova $i$ nacyyanal'naya kul'tura : aspekty uzaemadzeyannya : zb. navuk. art. I red. D. V. Dzyatko. Minsk : BDPU imya M. Tanka, 2009a. S. 54-57.

8. Ivanou Ya. Ya. Parehmiyalagichnyya sistemy belaruskaj i ruskaj mou: padabenstvy i razyhodzhanni. Filolohichni studii : Naukovyi visnyk Kryvorizkoho derzhavnoho pedahohichnoho universytetu. Kryvyi Rih : "Vydavnychyi dim", 2011. Vyp. 6. Ch. 2. S. 53-63.

9. Ivanou Ya. Ya., Ivanova S. F. Pol'ska-belaruski paremiyalagichny slounik = Polsko-białoruski słownik paremiołogiczny. Magilyou : MDU imya A. A. Kulyashova, 2007. 192 s.

10. Ivanou Ya. Ya. Sacyyalingvistychnyya parametry belaruskih prykazak (da prablemy vyznachehnnya paremiyalagichnaga minimumu i asnounaga paremiyalagichnaga fondu suchasnaj belaruskaj litaraturnaj movy). Mova i socyum: zb. navuk. prac / pad red. Ya. Ya. Ivanova. Magilyou : Brama, 2004. S. 201-224.

11. Ivanou Ya. Ya. Universal'nae i nacyyanal'nae u frazealagichnaj i paremiyalagichnaj padsistemah belaruskaj movy u eurapejskim mounym kanteksce (aktual'nasc', metadalogiya, perspektyvy dasledavannya). Slavyanskaya 
frazeologiya $v$ sinhronii i diahronii : sb. nauch. st. / red. V. I. Koval'. Gomel' : GGU im. F. Skoriny, 2016. Vyp. 3. S. 46-49.

12. Kotova M. Yu. Russko-slavyanskij slovar' poslovic s anglijskimi sootvetstviyami. Sankt-Peterburg : Izd-vo SPbGU, 2000. $360 \mathrm{~s}$.

13. Lepeshau I. Ya., Yakalcehvich M. A. Tlumachal'ny slounik prykazak. Grodna : GrDU, 2011. 695 s.

14. Lepeshau I. Ya. Paremiyalogiya yak asobny razdzel movaznaustva. Grodna : GrDU imya Yanki Kupaly, 2006. 279 s.

15. Lepeshau I. Ya. Etymalagichny slounik prykazak. Minsk: Vyshejshaya shkola, 2014. $141 \mathrm{~s}$.

16. Mudrost' slova skvoz' veka i narody: desyatiyazychnyj slovar' frazeologicheskih ehkvivalentov: okolo 700 latinskih poslovic, pogovorok, izrechenij / pod red. N. A. Goncharovoj. Minsk : Belaruskaya navuka, 2015. 479 s.

17. Permyakov G. L. Klassifikaciya poslovichnyh izrechenij. Sistema logicheskoj transformacii poslovic. Osnovy strukturnoj paremiologii. Moskva : Nauka, 1988a. S. 11-33.

18. Permyakov G. L. O smyslovoj strukture i sootvetstvuyushchej klassifikacii poslovichnyh izrechenij. Osnovy strukturnoj paremiologii. Moskva : Nauka, $1988 \mathrm{~b}$. S. 107-134.

19. Permyakov G. L. Universal'nyj tematicheskij ukazatel'. Osnovy strukturnoj paremiologii. Moskva : Nauka, 1988v. S. 170-181.

20. Petrusheuskaya Ju. A. Da prablemy razmezhavannya universal'naga i internacyyanal'naga u paremiyalagichnym fondze movy // Universal'noe i nacional'noe v yazykovoj kartine mira : materialy II Mezhdunar. nauch. konf., 14 15 oktyabrya 2016 g. / red. N. V. Furashova. Minsk, 2017a. S. 193-196.

21. Petrusheuskaya Ju. A. Da prablemy razmezhavannya universal'nyh i internacyyanal'nyh adzinak u paremiyalagichnym fondze belaruskaj movy. Itogi nauchnyh issledovanij uchenyh MGU imeni A. A. Kuleshova 2016 g. : materialy konferencii, 25 yanvarya 1 fevralya 2017 g. / pod red. E. K. Sychovoj. Mogilev, 2017b. S. 113-115.

22. Petrusheuskaya Ju. A. Pahodzhanne i tekstavyya krynicy nekatoryh universal'nyh prykazak u suchasnaj belaruskaj move. Tekst. Yazyk. Chelovek: sb. nauch. trudov : v 2 ch. / red. S. B. Kurash. Mozyr' : MGPU imeni I. P. Shamyakina, 2015a. CH. 2. C. $120-122$.

23. Petrusheuskaya Ju. A. Pra sferu uzhyvannya i pahodzhanne prykazki 'Adna galava dobra, a dzve lepsh'. Vestnik Minskogo gos. lingv. un-ta. Seriya 1, Filologiya. 2015b. № 5 (78). S. 84-96.

24. Petrusheuskaya Ju. A. Pra sferu uzhyvannya i pahodzhanne prykazki 'Z vyalikaga gromu maly dozhdzh'. Rodnae slova. 2016a. № 1. S. 44-47.

25. Petrusheuskaya Ju. A. Pra sferu uzhyvannya i pahodzhanne prykazki 'Hto mazha, toj i edze'. Vestnik Polockogo gos. un-ta. Seriya A, Gumanitar. nauki. 2016b. № 2. C. 138-144.

26. Petrusheuskaya Ju. A. Universal'ny, internacyyanal'ny i nacyyanal'ny kampanenty paremiyalagichnaga fondu suchasnaj belaruskaj litaraturnaj movy (na matehryyale publicystychnyh tekstau). Filolohichni studii : Naukovyi visnyk 
Kryvorizkoho derzhavnoho pedahohichnoho universytetu. Kryvyi Rih : FOP Marynchenko S. V., 2017. Vyp. 16. S. 195-201.

27. Petrusheuskaya Ju. A. Universal'nyya prykazki u belaruskaj move (leksikagrafichny aspekt). Uskhodneslavyanskiya movy u suchasnaj leksikagrafii : zb. navuk. art. / navuk. red. D. V. Dzyatko. Minsk : BDPU imya M. Tanka, 2015v. S. 84-87.

28. Ivanov E. Paremiological Minimum of the Belarusian Language. Dasledavanni pa germanskaj $i$ slavyanskaj filalogii $=$ Acta Germano-Slavica $: \mathrm{zb}$. navuk. art. / pad rehd. Ya. Ya. Ivanova. Magilyou : MDU imya A. A. Kulyashova, 2008. Vyp. 3. S. 283-302.

29. Ivanov E., Feldman V. Principles of the Contrastive Description of Aphoristic Paremiology (in Belarussian and Russian Languages). Dasledavanni pa germanskaj $i$ slavyanskaj filalogii = Acta Germano-Slavica $:$ zb. navuk. art. / pad rehd. Ya. Ya. Ivanova. Magilyou : MDU imya A. A. Kulyashova, 2007. Vyp. 1. S. 85-97.

30. Paczolay G. European Proverbs in 55 Languages, with Equivalents in Arabic, Persian, Sanskrit, Chinese, and Japanese. Veszprém (Hungary) : Veszprémi Nyomda, 1997. $528 \mathrm{p}$.

31. Proverbia et dicta: shestiyazychnyj slovar' poslovic, pogovorok i krylatyh slov / pod red. N. A. Goncharovoj. 2-e izd. Minsk : Konkurs, 2008. 352 s.

32 Strauss E. Dictionary of European proverbs : 3 vols. London \& New York : Routledge, 1994. Vol. 1. XIII, 625 p. ; Vol 2. V, 627-1232 p. ; Vol. 3. V, 789 p.

Стаття надійшла до редакиії 29.08.2018 p. Прийнята до друку 15.11. 2018 p. 